ISSN $1978-3000$

\title{
Pengaruh Pemberian Air Nanas (Ananas cosumus) terhadap Kualitas Daging Ayam Petelur Afkir
}

\author{
Effect of Suppliying Extracts (Ananas Cosumus) as Drinking Water \\ on Meat Quality of Culled Layers \\ Yosi Fenita, Olfa Mega Dan Eva Daniati. \\ Jurusan Peternakan Fakultas Pertanian Universitas Bengkulu \\ Jalan Raya Kandang Limun, Bengkulu. Telp. (0736) 2170 pst.219.
}

\begin{abstract}
The research was conducted from $6^{\text {th }}-27^{\text {th }}$ june 2008 in Commercial Zone animal Laboratory of animal Science departement, facultry of agriculture, and University, and University of Bengkulu. Aim of the research was to investigate the effect of supplying pineapple extracts (Ananas cosumus) as drinking water on meat quality of culled layers.. Research design used was completely randomized design. The treatmants were P) (control group), P1 (1 week supply of pineapple extract as drinking water prior slaughtering), P2 (2 weeks supply of pineapple extract as drinking water prior slaughtering)and P3 (3 weeks supply of pineapple extract as drinking water prior slaughtering). The collected data were analyzed by using analysis of variance, any significant results would be further tested with Duncand Multiple range test (DMRT). Vriable observed were meat $\mathrm{pH}$, tenderness, abdominal fat, cooking loss, water intake, and organoleptic test (color, odour and taste). Results showed that supplying pineapple extracts (Ananas cosumus) as drinking water significantly decreased level of abdominal fat, increased tenderness and cooking loss and significant on orgaleptic test $(\mathrm{P}<0.05)$; however, there was insignificant effect on meat $\mathrm{pH}$ and water intake. To sum up, supplying pineapple extracts (ananas cosumus) as drinking water for 3 weeks had resulted in a better meat than control group, as it increased the tenderness.
\end{abstract}

Key word : ananas cosumus, meat quality, layer.

\begin{abstract}
ABSTRAK
Penelitian ini bertujuan untuk mengetahui pengaruh pemberian air buah nanas (Ananas cosumus) terhadap kualitas daging ayam petelur afkir. Rancangan percobaan yang digunakan adalah Rancangan Acak Lengkap (RAL) 4 perlakuan dan 4 ulangan. Perlakuannya adalah (P0) pemberian air minum tanpa air nanas, (P1) pemberian air nanas selama satu minggu sebelum dipotong, (P2) pemberian air nanas selama dua minggu sebelum dipotong, (P3) pemberian air nanas selama tiga minggu sebelum dipotong. Data yang diperoleh dianalisis dengan sidik ragam (ANOVA), bila terdapat pengaruh yang nyata diuji dengan Duncan Multiple Range Test (Steel dan Torrie, 1993). Variabel yang diamati yaitu $\mathrm{pH}$ daging, keempukan daging, lemak abdominal, cooking loss, konsumsi air minum, dan uji organoleptik (warna, bau, dan rasa). Hasil penelitian menunjukkan bahwa pemberian air buah nanas secara nyata $(\mathrm{P}<0,05)$ dapat menurunkan lemak abdominal, dan meningkatkan keempukan daging, susut masak, uji organoleptik namun tidak berpengaruh nyata terhadap $\mathrm{pH}$ daging dan konsumsi air minum. Apabila dilihat secara kuantitatif keempukan daging dengan pemberian air buah nanas selama tiga minggu lebih baik dari kontrol.
\end{abstract}

Kata kunci: air nanas, daging, kualitas, petelur afkir

\section{PENDAHULUAN}

Ayam petelur merupakan salah satu jenis unggas yang memiliki potensi untuk dipelihara secara komersial. Tujuan utama pemeliharaan ayam petelur adalah untuk menghasilkan telur, tetapi ayam ini dapat juga menghasilkan daging setelah habis masa produksinya (diafkir). 
Masyarakat atau konsumen pada saat ini lebih selektif dalam memilih daging terutama masyarakat perkotaan, yang cenderung memilih daging dengan kriteria warna karkas yang kuning, warna daging merah cerah, bau tidak amis, kadar lemak rendah, perdagingan yang banyak dan tingkat kontaminasi daging yang rendah. Oleh karena itu, perlu diupayakan produksi daging yang berkualitas baik dan sesuai dengan selera konsumen.

Ayam petelur afkir biasanya memiliki daging yang keras atau alot (Hardjosworo dan Rukmiasih, 2002). Anam et al. (2003) menyatakan keempukan daging ayam petelur afkir dapat ditingkatkan dengan penambahan enzim bromelin yang terdapat dalam buah nanas, buah nanas sebanyak 15\% efektif untuk meningkatkan tingkat keempukan daging (Widjiati, 2005). Sibuea (2002) menyatakan air buah nanas (Ananas cosumus) juga mengandung serotonin sebesar 1,7-3,15 miligram/100 gram dalam sari buah nanas, serotonin merupakan suatu senyawa yang dapat menurunkan kadar lemak sebesar 10\% dari berat badan. Buah nanas juga mengandung mineral seperti kalium dan fosfor (Rismunandar, 1990). Kalium sangat berperan dalam meningkatkan rasa daging sementara fosfor berperan untuk meningkatkan kandungan mineral dalam daging.

Berdasarkan keterangan tersebut maka penulis tertarik untuk melakukan penelitian tentang pengaruh pemberian air

Tabel 1. Komposisi bahan penyusun ransum yang digunakan

\begin{tabular}{lcccccc}
\hline Bahan Pakan & Protein $(\%)$ & ME $(\mathrm{Kkal} / \mathrm{kg})$ & $\mathrm{Ca}(\%)$ & $\mathrm{P}(\%)$ & Lemak L $(\%)$ & SK $(\%)$ \\
\hline Jagung & $9,27^{\mathrm{b}}$ & $3370^{\mathrm{a}}$ & $0,06^{\mathrm{b}}$ & $0,29^{\mathrm{b}}$ & $3,9^{\mathrm{a}}$ & $2,82^{\mathrm{b}}$ \\
Dedak & $13,81^{\mathrm{b}}$ & $1630^{\mathrm{a}}$ & $0,1^{\mathrm{b}}$ & $1,94^{\mathrm{b}}$ & $4,85^{\mathrm{b}}$ & $5,49^{\mathrm{b}}$ \\
KLK & 33 & 3400 & $10,8^{\mathrm{e}}$ & 1 & $3,5^{\mathrm{e}}$ & $7^{\mathrm{e}}$ \\
Min. Mix & 0 & 0 & $32,5^{\mathrm{d}}$ & $10^{\mathrm{d}}$ & 0 & 0 \\
\hline
\end{tabular}

karena enzim bromelin mampu memecah ikatan protein komplek dan merupakan katalis reaksi hidrolisis protein dalam daging. Selain itu, Haryanto dan Hendarto (1982) juga menyatakan bahwa keempukan daging dapat ditingkatkan dengan pemberian air nanas (Ananas cosumus). Hal ini diduga karena adanya enzim bromelin yang bersifat basa. Widjiati (2005) menyatakan pemberian air nanas efektif untuk meningkatkan sifat organoleptik (rasa, warna, aroma, dan keempukan) serta kualitas protein daging.

Air buah nanas (Ananas cosumus) kaya akan enzim bromelin. Pemberian air nanas (Ananas cosumus) terhadap kualitas daging ayam petelur afkir.

\section{MATERI DAN METODE}

Penelitian ini dilaksanakan mulai tanggal 6 sampai 27 Juni 2007 selama 3 minggu di Kandang Peternakan Fakultas Pertanian Universitas Bengkulu. Alat yang digunakan dalam penelitian ini adalah tempat pakan, tempat minum, gelas ukur, timbangan analitik merk OHAUS, pisau, nampan, ember, blender, parutan, alat tulis, kantong plastik dan kandang baterai. 
Sedangkan bahan yang dibutuhkan 64 ekor ayam ras coklat strain platinum yang ada di kandang Peternakan, buah nanas, bahan pakan yang digunakan : jagung, dedak, KLK, Mineral suplemen.

Penelitian ini menggunakan Rancangan Acak Lengkap (RAL) dengan 4 perlakuan dan setiap perlakuan terdiri dari 4 ulangan. Setiap ulangan terdiri dari 4 ekor ayam, jadi jumlah ayam yang dibutuhkan sebanyak 64 ekor ayam ras coklat fase afkir umur 74 minggu.

Adapun keempat perlakuan tersebut adalah :

P0 : Tanpa pemberian air nanas (kontrol)

P1 : Pemberian air nanas selama 1 minggu sebelum dipotong

P2 : Pemberian air nanas selama 2 minggu sebelum dipotong

P3 : Pemberian air nanas selama 3 minggu sebelum dipotong

Apabila dari parameter yang diamati terdapat pengaruh nyata, maka dilakukan uji lanjut dengan menggunakan uji Duncan Multiple Range Test (Steel and Torrie,1993).

\section{Persiapan Kandang}

Kandang yang digunakan kandang baterai dimana setiap petak diisi 1 ekor ayam dan sebelum penelitian dilakukan sanitasi, setiap petak dilengkapi dengan tempat pakan dan tempat minum. Kandang dan peralatan yang ada di dalamnya disemprot dengan desinfektan.

\section{Pembuatan Air Nanas}

Buah nanas yang digunakan adalah buah yang sudah matang, buah tersebut dibersihkan dan dipotong-potong serta dihancurkan dengan blender atau parutan kemudian diperas dan diambil airnya. Air nanas diberikan sebanyak $15 \%$ dalam 1 liter air atau $150 \mathrm{ml}$ dalam 1 liter air minum.

\section{Penyusunan Ransum Penelitian}

Penyusunan ransum percobaan disusun dengan kandungan nutrisi bahan pakan yang digunakan berdasarkan pakan ayam ras coklat fase afkir pada imbangan $16 \%-18 \%$ protein (Wahyu, 1992).

\section{Pelaksanaan Penelitian}

Ayam yang digunakan adalah ayam ras coklat fase afkir dari kandang Peternakan, Universitas Bengkulu. Ayam

Tabel 2. Komposisi nutrisi ransum yang digunakan

\begin{tabular}{|c|c|c|}
\hline Bahan Pakan & & Konsumsi (\%) \\
\hline Jagung & & 40 \\
\hline Dedak & & 25 \\
\hline KLK & & 33 \\
\hline Min. Mix & & 2 \\
\hline Total & & 100 \\
\hline Protein (\%) & & 18,09 \\
\hline $\mathrm{EM}(\mathrm{Kkal} / \mathrm{kg})$ & & 2752,07 \\
\hline SK (\%) & & 4,81 \\
\hline Lemak (\%) & & 3,92 \\
\hline Ca $(\%)$ & & 4,26 \\
\hline $\mathrm{P}(\%)$ & & 1,13 \\
\hline keterangan : & $\begin{array}{l}\text { a. Wahyu (1992) } \\
\text { b. Fenita (2002) } \\
\text { c. Amrullah (2003) }\end{array}$ & $\begin{array}{l}\text { d. Label mineral Mix } \\
\text { e. Label KLK Super }\end{array}$ \\
\hline
\end{tabular}

Jurnal Sain Peternakan Indonesia Vol. 4, No 1. Januari - Juni 2009 
diambil secara acak sebanyak 64 ekor, kemudian ditimbang dan diberi label serta dimasukkan ke dalam petak kandang yang telah disediakan. Selama pemeliharaan ayam diberikan pakan dan air minum adlibitum. Pada setiap perlakuan ayam diambil 2 ekor secara acak kemudian disembelih dan diukur $\mathrm{pH}$ daging, keempukan, serta dihitung persentase lemak abdominal, susut masak/cooking loss dan lemak abdominal, uji organoleptik (warna, bau dan rasa).

\section{Variabel yang diamati}

1. pH Daging : Pengukuran $\mathrm{pH}$ dilakukan dengan cara mengambil sampel sebanyak 20 gram sampel, kemudian dihaluskan selama 2 menit dan ditambah aquades 40 $\mathrm{ml}$. Pengukuran $\mathrm{pH}$ dilakukan dengan $\mathrm{pH}$ meter, yang sebelumnya dikalibrasi dengan larutan buffer $\mathrm{pH} 7.0$ dan 4.0, pengukuran dilakukan 3 kali.

2. Keempukan Daging : Pengukuran keempukan daging diukur dengan menggunakan alat Shear Warner Bratzler Inston Testing Machine. Pada penelitian ini sampel dianalisis di Bogor (IPB).

3. Lemak Abdominal :Persentase lemak abdominal diperoleh dengan menimbang lemak yang menempel pada rongga perut dan dasar kloaka serta alat pencernaan.

\section{Cooking Loss}

Cooking loss diperoleh dari daging bagian dada yang dipotong dengan ukuran $1,5 \mathrm{~cm} \times 1,5 \mathrm{~cm}$ selanjutnya dikukus pada suhu $80^{\circ} \mathrm{C}$ selam 20 menit.

\section{Warna Daging}

Daging yang digunakan adalah daging segar, dengan metode skoring yang melibatkan 20 orang panelis. Dimana daging dinilai dengan memberikan skor 15, kelima skor tersebut mempunyai kriteria yaitu; skor 1 (tidak pucat), skor 2 (sedikit pucat), skor 3 (cukup pucat), skor 4 (pucat), skor 5 (sangat pucat).

\section{Bau dan Rasa}

Daging yang digunakan daging segar, dengan metode skoring yang melibatkan 20 orang panelis. Kriteria bau , skor 1 (sangat amis), skor 2 (amis), skor 3 ( agak amis), skor 4 (kurang amis), skor 5 (tidak amis). Uji rasa juga melibatkan panelis. Untuk uji rasa sampel diproses dengan pengukusan pada temperatur $80^{\circ} \mathrm{C}$ selama 20 menit. Kriteria rasa, skor 1 (rasa tidak enak), skor 2 (kurang enak), skor 3 (cukup enak), skor 4 (enak), skor 5 (sangat enak).

Preferensi untuk rasa daging menggunakan rasa kaldu sebagai berikut:

Skor 1: rasa tidak enak (10 gram $/ 500 \mathrm{ml}$ air); Skor 2: rasa kurang enak (40 gram/500 $\mathrm{ml}$ air); Skor 3: rasa cukup enak (70 gram/500 ml air); Skor 4: rasa enak (100 gram $/ 500 \mathrm{ml}$ air); Skor 5: rasa sangat enak (230 gram/500 ml air)

\section{HASIL DAN PEMBAHASAN}

Pengaruh perlakuan pemberian air buah nanas terhadap $\mathrm{pH}$ daging, keempukan daging, persentase lemak abdominal, susut masak dan konsumsi air minum dapat dilihat pada tabel 3 .

Hasil sidik ragam menunjukkan bahwa pemberian air buah nanas berpengaruh nyata terhadap $\mathrm{pH}$ daging $(\mathrm{P}<0,05)$. Hasil uji lanjut menunjukkan bahwa P0 tidak berbeda dengan P1 tetapi nyata lebih rendah dibandingkan dengan P2. Berdasarkan hasil penelitian terlihat bahwa pemberian air nanas memperlihatkan pengaruh yang baik terhadap $\mathrm{pH}$ daging. Hal ini dapat dilihat dari rataan $\mathrm{pH}$ daging yang mengalami kenaikan, dan ini menunjukkan bahwa aktivitas enzim bromelin yang terdapat dalam buah nanas optimal pada $\mathrm{pH}$ 6,5 dan pada kondisi ini enzim memiliki konfirmasi yang lebih bagus jika dibandingkan dengan $\mathrm{pH}$ rendah. Enzim ini juga berfungsi untuk memecahkan 
protein dalam pengempukan daging dan tidak merubah $\mathrm{pH}$ daging secara total serta membentuk cairan daging yang lebih baik. Menurut Soeparno (1996), pH daging yang normal berkisar antara 5,4-5,6 dan menyatakan bahwa semakin tinggi $\mathrm{pH}$ daging maka keempukan daging tersebut juga akan meningkat karena terjadinya kontraksi serabut otot.

\section{Keempukan Daging}

Hasil sidik ragam menunjukkan perlakuan pemberian air buah nanas berpengaruh sangat nyata $(\mathrm{P}<0,01)$ terhadap keempukan daging. Perbedaan ini terlihat dari peningkatan keempukan pada P1 sebesar 3,04\%, P2 sebesar 8,96\% dan P3 sebesar 22,31\% terhadap kontrol. Hasil uji lanjut menunjukkan bahwa P0 tidak berbeda nyata dengan $\mathrm{P} 1$, tetapi nyata lebih rendah dengan P2 dan P3. Hal ini disebabkan enzim proteolitik yang terkandung dalam nanas akan mempengaruhi komposisi daging pada tenunan pengikat. Whitaker (1959) dan Meyer (1975) dalam Suryanto (2004), menyatakan bahwa enzim proteolitik mampu memecah atau mengkatalisis protein daging menjadi molekul yang lebih sempurna berupa peptida dan asam amino. Semakin banyak protein daging yang terurai melalui pemutusan kimiawi akan menyebabkan struktur daging menjadi terbuka serta akan meningkatkan keempukan daging.

Lama pemberian air buah nanas pada ayam petelur afkir diikuti dengan peningkatan keempukan daging yang sangat nyata $(\mathrm{P}<0,01)$. Hal ini sesuai dengan Reed (1975) dalam Suryanto (2004), bahwa pemberian enzim proteolitik nyata meningkatkan keempukan daging dan konsentrasi enzim yang lebih tinggi akan mempunyai kesanggupan untuk mengempukkan daging yang lebih baik.

\section{Persentase Lemak Abdominal}

Hasil sidik ragam menunjukkan bahwa perlakuan pemberian air buah nanas berpengaruh sangat nyata terhadap kadar lemak abdominal $(\mathrm{P}<0,01)$. Uji lanjut Duncan menunjukkan bahwa P0 berbeda sangat nyata terhadap P1, P2 dan P3. Perbedaan ini jelas sekali ditunjukkan pada setiap perlakuan, dimana dari setiap perlakuan mengalami penurunan kadar lemak abdominal, dimulai dari P1 mengalami penurunan kadar lemak abdominal sebesar 36,36 \%, P2 sebesar $56,25 \%$, dan P3 sebesar 59,67\% dibanding P0. Hal ini membuktikan pemberian air buah nanas dari P1 sampai P3 efektif menurunkan kadar lemak abdominal. Kenyataan ini sesuai dengan pendapat Sibuea (2002), bahwa air buah nanas

Tabel 3. Rataan $\mathrm{pH}$ daging $\mathrm{pH}$ daging, keempukan daging, persentase lemak abdominal, susut masak dan konsumsi air minum

\begin{tabular}{llllll}
\hline \multicolumn{1}{c}{ Variabel } & \multicolumn{1}{c}{$\mathrm{P} 0$} & \multicolumn{1}{c}{$\mathrm{P} 1$} & \multicolumn{2}{c}{$\mathrm{P} 2$} & $\mathrm{P}$ \\
\hline pH daging & $5.73^{\mathrm{a}}$ & $5.76^{\mathrm{a}}$ & $5.98^{\mathrm{a}}$ & 6.05 & $*$ \\
Keempukkan (gram/fost) & $1540.6^{\mathrm{a}}$ & $1493.7^{\mathrm{ab}}$ & $1403^{\mathrm{b}}$ & $1196.8^{\mathrm{c}}$ & $* *$ \\
Lemak abdominal & $1.76^{\mathrm{a}}$ & $1.12^{\mathrm{b}}$ & $0.77^{\mathrm{c}}$ & $0.71^{\mathrm{c}}$ & $* *$ \\
Susut masak & 25.56 & 25,93 & 24,62 & 26,09 & $\mathrm{~ns}$ \\
Konsumsi air minum & 1182,9 & 1197,2 & 1199.9 & 1207.9 & $\mathrm{~ns}$ \\
\hline
\end{tabular}

Keterangan : Superskrip yang berbeda menunjukkan berbeda nyata $(\mathrm{P}<0,05)$ 
mengandung serotonin yang berfungsi mengatasi stres dan menurunkan kadar kolesterol dalam darah yang akhirnya akan menurunkan kadar lemak. Muramatsu (1986) dalam Santoso (1999), menyatakan bahwa zat-zat aktif seperti Saponin, vitamin C, flavonoid, dan tanin juga mampu menurunkan akumulasi lemak.

\section{Persentase Susut Masak (Cooking Loss)}

Hasil sidik ragam menunjukkan bahwa perlakuan tidak memberikan pengaruh yang nyata terhadap susut masak ( $P>0,05)$. Walaupun demikian pada persentase susut masak terjadi peningkatan pada P1 dan P3 yaitu sebesar 1,44\%, dan $2,07 \%$ dan terjadi penurunan pada perlakuan P2 sebesar $3,67 \%$ bila dibandingkan dengan kontrol. Secara umum pemberian air buah nanas memperlihatkan pengaruh yang baik kehilangan nutrisi selama pemasakan akan lebih sedikit.

\section{Konsumsi Air Minum}

Hasil sidik ragam menunjukkan kenaikan yang tidak nyata $(\mathrm{P}>0,05)$ terhadap konsumsi air minum seiring dengan bertambahnya lama pemberian air buah nanas, tetapi terjadi peningkatan konsumsi air minum dari setiap perlakuan. Kenaikan konsumsi air minum pada penelitian ini disebabkan karena air minum pada P1, P2, P3 memiliki kandungan nutrisi seperti vitamin dan mineral yang lebih baik dibandingkan dengan kontrol (P0). Menurut Wahyu (2003), faktor yang dapat menurunkan atau menaikkan konsumsi air minum antara lain adalah tingkat garam natrium dan kalium dalam ransum, tingkat protein, serat kasar, dan enzim.

Tabel 4. Rataan skor warna, bau dan rasa daging

\begin{tabular}{lccc}
\hline & \multicolumn{2}{c}{ Rataan } & \\
\cline { 2 - 4 } Perlakuan & Warna & Bau & Rasa \\
\hline P0 & $1,94^{\mathrm{a}}$ & $2,52^{\mathrm{c}}$ & $1,60^{\mathrm{c}}$ \\
P1 & $2,37^{\mathrm{ab}}$ & $2,87^{\mathrm{bc}}$ & $2,10^{\mathrm{b}}$ \\
P2 & $2,42^{\mathrm{ab}}$ & $3,31^{\mathrm{b}}$ & $2,93^{\mathrm{a}}$ \\
P3 & $2,70^{\mathrm{b}}$ & $3,94^{\mathrm{a}}$ & $3,31^{\mathrm{a}}$ \\
\hline Sd & 0,31 & 0,61 & $0,77^{\mathrm{a}}$ \\
\hline
\end{tabular}

Keterangan : Superskrip yang berbeda menunjukkan berbeda sangat nyata $(\mathrm{P}<0,01)$

terhadap persentase susut masak walaupun belum menunjukkan penurunan cooking loss yang nyata dari perlakuan kontrol, namun masih dalam kisaran normal. Soeparno (1996), menyatakan bahwa daging dengan susut masak yang lebih rendah mempunyai kualitas yang relatif lebih baik dari pada daging dengan susut masak yang lebih besar, karena
Uji Organoleptik (Warna, Bau, dan Rasa daging)

Pengaruh pemberian air buah nanas terhadap uji organoleptik (warna, bau, dan rasa) daging dapat dilihat padaTabel 4. Berdasarkan hasil sidik ragam perlakuan pemberian air buah nanas berpengaruh nyata terhadap warna daging 
ISSN $1978-3000$

$(\mathrm{P}<0,05)$. Terlihat dari table 10 bahwa skor warna daging meningkat dengan bertambahnya lama perlakuan. Kenaikan ini membuktikan pemberian air buah nanas terhadap daging akan semakin pucat seiring dengan bertambahnya lama pemberian air buah nanas. Kenyataan ini sesuai dengan pendapat Anam et al. (2003), semakin tinggi konsentrasi enzim bromelin yang terdapat aktivitas merubah warna daging semakin cepat, sehingga warna daging menjadi pucat.

Pemberian air buah nanas berpengaruh nyata $(\mathrm{P}<0,05)$ terhadap bau daging. Hal ini menunjukkan pemberian air buah nanas mengurangi bau amis daging jika dibandingkan dengan kontrol. Penurunan bau yang relatif tinggi terdapat pada P3 dan P2 yaitu sebesar 56,34 \% dan $31,34 \%$ sedangkan pada P1 peningkatan sebesar 13,88 \%, jika dibandingkan dengan kontrol. Menurut Winarno (1993) bahwa bau yang tidak sedap disebabkan oleh perubahan ATP menjadi hipoksantin setelah 2-3 jam ternak dipotong.

Sedangkan perlakuan pemberian air buah nanas juga memberikan pengaruh yang nyata $(\mathrm{P}<0,05)$ terhadap rasa daging, dari rasa tidak enak menjadi cukup enak, dimana P1, P2, P3 secara nyata berbeda dengan kontrol dan terjadi peningkatan kearah yang semakin baik (rasa cukup enak) dengan bertambah lamanya perlakuan. Air buah nanas mengandung kalium yang dapat meningkatkan rasa daging. Rasa daging juga ditentukan oleh pemecahan ATP menjadi beberapa senyawa diantaranya Inosine mono Phospat (IMP) yang merangsang timbulnya komponen lezat dan cita rasa daging yang enak (Winarno, 1993).

\section{SIMPULAN}

\section{Kesimpulan}

Berdasarkan hasil penelitian menunjukkan perlakuan pemberian air buah nenas terhadap ayam petelur afkir dapat menurunkan persentase lemak abdominal, meningkatkan keempukan daging, $\mathrm{pH}$ daging, dan meningkatkan cita rasa dan mengurangi bau amis yang terdapat pada daging, tetapi tidak dapat memperbaiki susut masak (cooking loss) dan warna daging.

\section{Saran}

Perlu dilakukan penelitian lanjut mengenai pengaruh perbedaan konsentrasi dan lama waktu pemberian air nenas terhadap kualitas daging pada ayam petelur afkir.

\section{DAFTAR PUSTAKA}

Amrullah, I. B. 2003. Nutrisi Ayam Petelur. Cetakan 1. Lembaga Satu gunung budi, Bogor.

Anam, C., N, S. Rahayu, dan M, Baedowi. 2003. Aktivitas Enzim Bromelin terhadap Mutu Fisik Daging. Jurnal Seminar Nasional dan Pertemuaan Tahunan Perhimpunan Ahli Teknologi Pangan Indonesia (PATPI) Peranan Industri Dalam pengembangan Produk Pangan Indonesia-Yogyakarta.

Anggorodi, R. 1997. Ilmu Makanan Ternak Umum. Gramedia, Jakarta.

Fenita, Y. 2002. Suplementasi lisin dan metionin serta minyak ikan lemuru kedalam ransum berbasis hidrolisa bulu ayam terhadap perlemakan dan pertumbuhan ayam ras pedaging. Disertasi. Program pasca Sarjana. Intitut Pertanian Bogor, Bogor. 
Gasperz, V. 1994. Metode Perancangan Percobaan. Penerbit Armico, Bandung.

Hardjosworo, P.S. dan Rukmiasih. 2002. Meningkatkan Produksi Daging Unggas. Penebar Swadaya, Jakarta.

Haryanto, E. dan B. Hendarto. 1996. Nanas. Penebar Swadaya, Jakarta.

Maryanto. 2002. Pengaruh aneka produk fermentasi kotoran ayam petelur terhadap kualitas karkas ayam broiler. Skripsi. Fakultas Pertanian. Jurusan Peternakan Universitas Bengkulu, Bengkulu.

Pracaya. 1982. Bertanam Nenas. Penebar Swadaya, Jakarta.

Rismunandar. 1990. Membudidayakan Tanaman Buah-buahan. Penerbit Sinar Baru, Bandung.

Rizal, Y. 1999. Teknik Penyusunan dan Pemberian Pakan serta Alternatif untuk Ayam Ras. Makalah dan Bahan Pelatihan untuk Peternak Ayam Ras Di Kabupaten 50 kota

Rukmana, R. 1996. Nenas, Budidaya dan Pasca Panen. Kanisius, Yogyakarta.

Santoso, U. 1999. Pengaruh cara pemberian daun katuk (Sauropus androgynus) terhadap performans dan penimbunan lemak pada ayam pedaging. Jurnal Ilmu Ternak 7(3):144-146.
Steel, R.G.D., dan J.H. Torrie. 1980. Princples Procedures of Statistic. Diterjemahkan oleh Sumantri, B. 1993. Prinsip dan Prosedur Statistika "Suatu Pendekatan Biometrik" . PT. Gramedia Pustaka Utama, Jakarta.

Sibuea. P. 2002. Manfaat Nenas Untuk Kesehatan. http://www.google. co.id/ Nenas.

Soeparno. 1996. Ilmu dan Teknologi Daging. Gadjah Mada University Press, Yogyakarta.

Suryanto, D. 2002. Pengaruh Konsentrasi Enzim Papain dan Suhu Penyimpanan terhadap Daya Ikat Air dan $\mathrm{pH}$ Daging. Jurnal Ilmu Ternak Vol:4(1):27-29.

Tillman, A.D., H. Hartadi, S. Lebdosukojo. 1989. Ilmu Makanan Ternak Dasar. Gadjah Mada University Press, Yogyakarta.

Wahyu, J. 1992. Ilmu Nutrisi Unggas. Cetakan ketiga . Gadjah Mada University Press, Yogyakarta.

Widjiati. 2005. Aplikasi Enzim Bromelin sebagai Biokatalisator pada Pembuatan Daging Sintesis http://www.google.co.id/bromelin.

Winarno. F. G. 1993. Enzim Pangan. Gramedia, Jakarta. 